\title{
Prevalence of hepatitis $C$ in donors from the Alagoas blood center
}

\author{
Fernanda Farias de Santos*, Valesca Patriota de Souza**, Joelma \\ Carvalho Santos*, Larissa Isabella Oliveira de Souza***, Maíza Brito \\ Ramos Bezerra****, Gláucia Manoella de Souza Lima******
}

\begin{abstract}
In this article, we sought to assess the prevalence of hepatitis $\mathrm{C}(\mathrm{HCV})$ as well as some socio-demographic characteristics of HCV-positive blood donors of the center of Alagoas. The medical records of donors from a blood center in Alagoas were analyzed. The enzyme-linked immunosorbent assay (ELISA) was used for detection of antibodies against HCV, within the period from 2001 to 2004. Samples with positive serology by ELISA were analyzed through the confirmatory RIBA test. 45,832 donations were collected at the blood center. Out of them, $0.62 \%$ had positive serology for hepatitis $\mathrm{C}$. With regard to the variables, there was a prevalence of $86.7 \%$ for males, with ages ranging from 31 to 40 years. Only 201 people returned to repeat ELISA. Out of these, $42.3 \%$ had repeated positive serology by ELISA. For confirmation by RIBA, only 97 donors returned: $55.4 \%$ were positive, $15.7 \%$ negative, and $9.1 \%$ indeterminate. The studies show the need for more specific serological screening tests.
\end{abstract}

Descriptors: Hepatitis C, Enzyme-linked immunosorbent assay, Blood donors.

\section{Prevalência da hepatite C em doadores do hemocentro de Alagoas}

Resumo: Neste artigo, buscou-se avaliar a prevalência de Hepatite C (HCV) bem como algumas características sócio-demográficas dos doadores de sangue HCV positivo do Hemocentro de Alagoas. Foram analisados os prontuários dos doadores de um hemocentro em Alagoas. Foi utilizado o ensaio de imunoadsorção enzimática (ELISA) para a detecção de anticorpos contra o VHC, no período de 2001 a 2004. Foram realizadas 45.832 doações no hemocentro. Destas, 0,62\% apresentaram sorologia reativa para hepatite $\mathrm{C}$. Em relação às variáveis, houve predominância de $86,7 \%$ para o sexo masculino, com idade entre 31 a 40 anos. Compareceram para repetição do ELISA apenas 201 pessoas. Destas, 42,3\% apresentaram sorologia repetidamente reagente pelo ELISA. Para confirmação pelo RIBA, apenas 97 doadores retornaram: 55,4\% foram reagentes, $15,7 \%$ não reagentes e $9,1 \%$ indeterminados. Os estudos apontam para a necessidade de uma triagem sorológica com testes mais específicos.

Descritores: Hepatite C, Ensaio de imunoadsorção enzimática, Doadores de sangue.

*Graduada em biomedicina pelo Centro de Ensino Superior de Maceió (CESMAC), Maceió, AL, Brasil. **Mestranda em Saúde Humana e Meio Ambiente na Universidade Federal de Pernambuco (UFPE), Vitória de Santo Antão, PE, Brasil.

***Mestranda em Ciências da Saúde na Universidade Federal de Alagoas (UFAL), Maceió, AL, Brasil. ****Farmacêutica. Docente no Centro de Ensino Superior de Maceió (CESMAC), Maceió, AL, Brasil.

*****Biomédica. Docente no Departamento de antibióticos na Universidade Federal de Pernambuco (UFPE), Recife, PE, Brasil. 


\section{Introduction}

Viral hepatitis represents a major public health problem worldwide, featuring an infectious process which affects, in varying degrees, the functioning of liver. ${ }^{1}$ Currently, there are five known types of viral hepatitis, classified as A, B, C, D, and E; there are also three other viruses that may be associated to hepatotropism as hepatitis $G$ virus (GBV), transmitted transfusion virus (TTV), and SEM-V. ${ }^{2}$

In the 1970s there was found evidence that the majority of cases of hepatitis due to blood transfusion was caused by a different type of virus; in the beginning, this virus was designated non-A and non-B. It was verified that the virus particle could persist and maintain the infection for a long time, and that its transmission occurred through the serum or plasma, afterwards this virus was named hepatitis $\mathrm{C}$ virus $(\mathrm{HCV}){ }^{3}$

$\mathrm{HCV}$ belongs to the family Flaviviridae. It is an enveloped RNA virus with single stranded genome of $9.7 \mathrm{~kb}$, positive polarity. ${ }^{4-5}$ The main forms of transmission of HCV occur through contact with blood and blood derivatives, via transfusion, shared use of contaminated needles and syringes, and transplantation of organs. ${ }^{1,6}$

About $70 \%$ of individuals infected with HCV are asymptomatic, complicating early detection, because the biochemical changes (e.g. the increase in serum transaminases and bilirubin) caused by liver dysfunction are small in cases of hepatitis $C .^{7-8}$

The number of chronic HCV patients in the world spans more than 180 million people. ${ }^{9}$ In Brazil, it is not possible to obtain this estimate, due to lack of data, but it is estimated that the prevalence of $\mathrm{HCV}$ is about $3 \%$ in the general population. ${ }^{4}$

In 1900, the blood and blood derivatives sector in Brazil faced technical problems because it did not have a specific health policy. Therefore, its activities were carried out empirically. After the emergence of cases of acquired immunodeficiency syndrome (AIDS), new policies began to be adopted. ${ }^{10}$ Then, in 1988 , with the advent of Law 7,649 , signed on January 25,1988 , the registration of blood donors and completion of laboratory tests of blood collected for hepatitis B, Chagas disease, Syphilis, Malaria, and AIDS became mandatory, in order to prevent the spread of these diseases. ${ }^{11}$

In 1993, Portaria 1,376 from the National Agency of Sanitary Surveillance (ANVISA) turned mandatory to include testing for HCV antibodies in the screening tests, in order to try to reduce the transmission of the two forms of hepatitis through blood transfusion. ${ }^{12}$

The importance of detection of HCV in donors through serological tests is remarkable, aiming to guarantee the quality of blood to be donated and, thereby, contributing to reduce the spread of infection in the population, generally, when using the blood bags supplied by blood centers.

This paper aims to evaluate the epidemiological profile of hepatitis $C$ in blood donors from a blood center in Alagoas, Brazil, through a study on the positivity of hepatitis markers in blood donors, taking into account the demographic and socioeconomic variables.

Saúde (Santa Maria), v.38, n.2, p. 37 - 44, 2012. Prevalence of hepatitis $\mathrm{C}$ in donors from the Alagoas blood center 


\section{Methods}

The medical records of 286 blood donors at the Maceio Blood Center, Alagoas, Brazil, within the period from January 2001 to December 2004, were analyzed; they showed reactive or indeterminate serology for HCV by enzyme-linked immunosorbent assay (ELISA). Seropositive samples by ELISA were analyzed through confirmatory RIBA test. The social characteristics of all donors with positive or indeterminate serology for HCV (gender, age, education level, skin color, and marital status) were also analyzed. Numerical variables were represented as means and standard deviation and the categories were represented with " $n$ " and total percentages.

In the analysis of variables, those with the lowest $p$-value in the chi-square test were considered representative. Means were compared through Student's t-test, and a p-value equal to or less than 0.05 was considered significant. The software used was GraphPad Prism.

This study was carried out in accordance with the ethical standards for studies involving human beings, and it was approved by the Research Ethics Committee of the School of Biological and Health Sciences of Centro Universitario CESMAC, with a favorable opinion issued on July 13, 2009, under the Protocol 664/09.

\section{Results and discussion}

From 2001 to 2004 45,832 donations were collected at the Blood Center of Maceio, with an annual average of 11,460 donors $( \pm 291)$. The annual average of donors with reactive serology for HCV was $71.50 \pm 10.76$. One can notice a small drop in the number of reagent donors for HCV in the last four years, with the exception of 2002. There was a statistical significance $(p<0.0001)$ regarding the number of donors with reactive serology (Table 1$)$.

Out of the 45,832 blood donors, $286(0.62 \%)$ showed reactive serology for hepatitis C using ELISA test. Among these donors, 201 underwent repeat ELISA test, and 121 (60.20\%) were positive again. Invited to return for confirmation, only 91 attended and the positive serology for HCV was present in $67(73.60 \%)$ of them (Table 2).

No significant difference was found with regard to skin color, marital status, education, and gender of blood donors with reactive serology for HCV. However, when it was used the RIBA test was evidenced greater prevalence of positive HCV in the group $>50$ years (Table 3).

A similar situation occurred when the social characteristics of these donors were analyzed, there is a variation of these characteristics at different stages of confirmatory tests, but one social characteristic showed an interesting profile, that is, most donors who returned for confirmatory testing had low education, demonstrating that this is not reflected in their knowledge level, while donors with higher education had a lesser attendance to perform the tests, indicating a low knowledge level on the part of these people.

In Brazil, according to data from ANVISA ${ }^{13}, 1.7 \%$ of the population donates blood and within this population the state of Alagoas represents $2 \%$ of the donations in the country. Blood centers are concerned with using increasingly more specific laboratory tests, aiming to

Saúde (Santa Maria), v.38, n.2, p. 37 - 44, 2012. Santos, F. F., et al. ISSN 2236-5843 increase the safety of blood derivatives supplied to the population. The standardized 
procedure at the blood center of Alagoas is to dispose the bags with repeated serological positive results by anti-HCV ELISA. Thus, reagent donors should have their positivity confirmed through more specific tests. Therefore, aiming to keep the donor, confirmation is performed with the immunoblot/RIBA test; but it is important to emphasize that the blood center of Alagoas used immunoblot/RIBA as a confirmatory test for HCV only from January 2001 to December 2004, corresponding to the study period of this research, because it has been determined that providing the diagnosis of infection to the donor is not a responsibility of the blood center.

In Brazil, still there are few studies showing the prevalence of hepatitis $\mathrm{C}$ among blood donors. Recently, ANVISA began to group the data and it shows that, in the Brazilian public blood centers, the prevalence of HCV infection among blood donors was $0.5 \%$ in 2002 .

Our results showed a HCV prevalence of $0,62 \%$ detected by ELISA test among donors from the blood center of Alagoas. In the period from 2000 to 2002, ANVISA observed a 0.69\% seroprevalence in the Northeast Region of the country and a $0.72 \%$ seroprevalence in the state of Alagoas. ${ }^{14}$ In São Luis, Maranhão, Brazil, some studies show a drop in the positivity rates of anti-HCV. In the period from 1994 to 1998 there was an $1.41 \%$ prevalence, by 2002 this number dropped to $0.54 \%$, confirming the data found by ANVISA. ${ }^{15}$

After the confirmatory tests (repeated ELISA and RIBA), the seroprevalence dropped from $0.62 \%$ to $0.15 \%$. Immunoenzymatic techniques can produce false-positive results due to the presence of some residual proteins of the microorganism used as a vector for cloning recombinant antigens which are present in the serological kits; it can also occur in autoimmune patients or in serum stored for long periods16. However, we cannot assert that this decreased seroprevalence after performing RIBA is a result of false positive generated by ELISA test since only $31.82 \%$ returned to confirm the results obtained previously.

The comparison between the tests showed that RIBA is a much more specific test, evidencing that ELISA test generates false-positive results. These results demonstrate the need for confirmation of screening tests.

There was a higher predominance of males (86.7\%) among reagent blood donors. This result confirms data presented by ANVISA ${ }^{14}$, where $79 \%$ of the donors' population is male.

It was shown that female participation in donations is very low throughout the country. Regardless of gender when was used the RIBA test, the results obtained showed that donors with reactive serology were aged from $>50$ years $(47.6 \%)$, single $(57.34 \%)$, and they had incomplete primary education (43.71\%).

Contrary to our results, one study did not observe any association to different age groups and genders. ${ }^{16}$ Another study observed a higher prevalence of males (83.6\%), aged from 26 to 45 years. ${ }^{17}$

A study carried out with 242,726 volunteer donors within the period 2004-2006 found that the largest group of donors consisted of males aged from 18 to 29 years, where $0.46 \%$ were serologically reactive for anti-HCV antibodies. ${ }^{18}$

\section{Conclusion}

Saúde (Santa Maria), v.38, n.2, p. 37 - 44, 2012. Prevalence of hepatitis $\mathrm{C}$ in donors from the Alagoas blood center

We observed that many donors with reactive serology on screening tests were not confirmed through more specific tests, as they did not return for further analyses. Thus, the results reinforce the need for performing a high quality serological analysis in blood centers, in 
order to provide an early diagnosis of hepatitis to this donor population and guarantee the quality of blood to be donated, thereby contributing to decrease the spread of infection in the population. In addition, the disposal of blood bags represents a great loss for the blood centers throughout the Country due to the difficulty of maintaining stocks of hemocomponents satisfactorily.

\section{References}

1. Poynard T, Yuen MF, Ratziu V, Lai CL. Viral hepatitis C. Lancet. 2003;20(9401):2095-100.

2. Ferreira C, Silveira TR. Hepatites virais: aspectos da epidemiologia e da prevenção. Rev Bras Enferm [journal on the internet]. 2004 [cited 2012 Apr 17];7:473-87.

3. Bradley DW, Maynard JE, Popper H, Cook EH, Ebert JW, McCaustland KA, et al. Posttransfusion non-a, nom-b hepatitis: physicochemical properties of two distinct agents. J Infect Dis. 1983;148(2):254-65.

4. Strauss E. Hepatite C. Rev Soc Bras Med Trop. 2001;34(1):69-82.

5. Berkhout $B$. Hepatitis $C$ virus therapy: blocking the little microRNA helper of the virus. J Formos Med Assoc. 2010;109(3):173-6.

6. Helen ST, Donald MJ. Epidemiology of hepatitis B and C viruses: a global overview. Clin Liver Dis. 2010;14(1):1-21.

7. Alter MJ. Epidemiology of hepatitis $\mathrm{C}$ virus infection. World $\mathrm{J}$ Gastroenterol [journal on the internet]. 2007 [cited 2012 Apr 17];13:2436-41.

8. Garcia FB, Pereira GA, Martins PRJ, Souza HM. Epidemiological profile of hepatitis C in blood donors at the Uberaba regional blood center. Rev Soc Bras Med Trop. 2009;42(1):1-4.

9. Ciorlia LAS, Zanetta DMT. Hepatite C em profissionais da saúde: prevalência e associação com fatores de risco. Rev Saúde Pública 2007;41(2):229-35.

10. Torezan G, Souza EM. Transfusão de hemoderivados: os enfermeiros estão preparados para 0 cuidado peritransfusional? Rev Enferm UFPE On Line [journal on the internet]. 2010 Apr/Jun [cited 2012 Apr 17];4(2):658-65.

11. Brasil. Lei n. 7.649, de 25 de janeiro de 1988: estabelece a obrigatoriedade do cadastramento dos doadores de sangue bem como a realização de exames laboratoriais no sangue coletado, visando a prevenir a propagação de doenças. Diário Oficial da União [journal on the internet]. 27 Jan 1988 [cited 2012 Apr 17].

12. Agência Nacional de Vigilância Sanitária [homepage on the internet]. Portaria n. 1.376, de 19 de novembro de 1993. Brasília (DF): Ministério da Saúde; 1993 [cited 2012 Apr 17].

13. Agência Nacional de Vigilância Sanitária [homepage on the internet]. Relatório de produção de 2004. Brasília (DF): Ministério da Saúde; 2004 [cited 2012 Apr 17].

14. Agência Nacional de Vigilância Sanitária [homepage on the internet]. Relatório de produção de hemoterápicos de 2000 a 2002. Brasília (DF): Ministério da Saúde; 2002 [cited 2012 Apr 17].

15. Soares MCP, Menezes RC, Martins SJ, Bensabath G. Epidemiologia dos vírus das hepatites B, C e D na tribo indígena parakaná, Amazônia Oriental Brasileira. Rev Panam Salud Pública. 1994;117(2):124-35.

16. Paltamin LF, Reiche EV. Soroprevalência de anticorpos antivírus da hepatite $C$ em doadores de sangue, Brasil. Rev Saúde Pública. 2002;36(4):393-9.

17. Valente VB, Covas DT, Passos ADC. Hepatitis $B$ and $C$ serologic markers in blood donors of the Ribeirão Preto Blood Center. Rev Soc Bras Med Trop. 2005;38(6):488-92.

Saúde (Santa Maria), v.38, n.2, p. 37 - 44, 2012. Santos, F. F., et al. 
18. Oliveira-Filho AB, Pimenta ASC, Rojas MFM, Chagas MCM, Crescente JAB, Crespo DM, et al. Prevalence and genotyping of hepatitis $C$ virus in blood donors in the state of Pará, Northern Brazil. Mem Inst Oswaldo Cruz. 2010;105(1):103-6.

19. Viana GMCV, Diniz-Neto JA, Binda-Júnior JR, Rabelo EMF, Costa MHA, Sousa JG, et al. Marcadores sorológicos de hepatites $\mathrm{B}$ e $\mathrm{C}$ em doadores de sangue no Estado de Maranhão, Brasil. Rev Panam Infectol. 2009;11(1):20-4.

\section{Fernanda Farias de Santos}

Endereço para correspondência - Departamento de antibióticos, UFPE. Av. Professor Arthur de Sá, s/n. Cidade universitária. Recife- PE

CEP: $50740-520$

E-mail: nandafaryas@hotmail.com

Currículo Lattes: http://lattes.cnpq.br/2543546571096294

Recebido em 21 de julho de 2012.

Aprovado em 29 de outubro 2012. 


\section{Addendum}

Table 1 - Number of blood donors who had positive serology for hepatitis $C$ at the Maceio Blood Center within the period from 2001 to 2004.

\begin{tabular}{ccc}
\hline & Donors & Positive serology for HCV \\
\cline { 2 - 3 } Year & $\mathrm{n}(\%)$ & $\mathrm{n}(\%)$ \\
\hline 2001 & $11,214(24.5)$ & $79(27.5)$ \\
2002 & $12,323(27)$ & $96(33.5)$ \\
2003 & $11,237(24.5)$ & $66(23)$ \\
2004 & $11,058(24)$ & $45(16)$ \\
\hline TOTAL & 45,832 & 286 \\
\hline
\end{tabular}

Table 2 - Results of serological tests for hepatitis $\mathrm{C}$ carried out in blood donors at the Maceio Blood Center within the period from 2001 to 2004.

\begin{tabular}{cccc} 
& \multicolumn{3}{c}{ SEROLOGICAL TEST } \\
\hline Anti-HCV & 1st ELISA & 2nd ELISA & RIBA \\
& $\mathrm{n}(\%)$ & $\mathrm{n}(\%)$ & $\mathrm{n}(\%)$ \\
\hline Positive & $286(0.62)$ & $121(60.20) \mathrm{a}$ & $67(73.60) \mathrm{a}$ \\
Inconclusive & & $7(3.50) \mathrm{b}$ & $3(3.30) \mathrm{b}$ \\
Negative & $45,546(99.39)$ & $73(36.30) \mathrm{c}$ & $21(23.10) \mathrm{c}$ \\
\hline TOTAL & 45,832 & 201 & 91 \\
\hline
\end{tabular}

$p$-value $>0.05$ for $a, b$ and $c$. Student's t-test.

Table 3 - Age group of blood donors at the Maceio Blood Center within the period from 2001 a 2004.

\begin{tabular}{|c|c|c|c|c|c|c|c|}
\hline \multirow{2}{*}{\multicolumn{2}{|c|}{ Social }} & \multicolumn{5}{|c|}{ Positive serology } & \multirow{3}{*}{$\begin{array}{c}p- \\
\text { value }\end{array}$} \\
\hline & & 1st ELISA & \multicolumn{2}{|c|}{ 2nd ELISA } & \multicolumn{2}{|c|}{ RIBA } & \\
\hline & $\mathrm{N}$ & $\%$ & $\mathrm{~N}$ & $\%$ & $\mathrm{~N}$ & $\%$ & \\
\hline \multicolumn{8}{|c|}{ Age group (years) } \\
\hline $24-30$ & 35 & 12.24 & 9 & 7.40 & 5 & 7.50 & \multirow{4}{*}{0.0052} \\
\hline $31-40$ & 90 & 31.46 & 32 & 26.50 & 11 & 16.40 & \\
\hline $41-50$ & 83 & 29.00 & 36 & 29.80 & 19 & 28.50 & \\
\hline$>50^{*}$ & 78 & 27.30 & 44 & 36.30 & 32 & 47.60 & \\
\hline Total & 286 & 100.00 & 121 & 100.00 & 67 & 100.00 & \\
\hline
\end{tabular}

${ }^{*} p$-value: $<0.0052$, with statistical significance.

Saúde (Santa Maria), v.38, n.2, p. 37 - 44, 2012 Santos, F. F., et al. 
Saúde (Santa Maria), v.38, n.2, p. 37 - 44, 2012. Prevalence of hepatitis $\mathrm{C}$ in donors from the Alagoas

blood center

44 | ISSN 2236-5834 